\title{
Capital Structure Determinants in Family Firms: An Empirical Analysis in Context of Crisis
}

\author{
Stefania Migliori ${ }^{1}$, Fabrizio Maturo ${ }^{1}$, \& Francesco Paolone ${ }^{2}$ \\ ${ }^{1}$ Department of Management and Business Administration, "G. d'Annunzio" University of Chieti-Pescara, V.le \\ Pindaro, n. 42, 65127-Pescara, Italy \\ ${ }^{2}$ Department of Management and Business Administration, University of Naples, Via Generale Parisi, n. 13, \\ 80132- Naples, Italy \\ Correspondence: Stefania Migliori, Department of Management and Business Administration, "G. d'Annunzio" \\ University of Chieti-Pescara, V.le Pindaro, n. 42, 65127-Pescara, Italy.
}

Received: February 1, 2018

Accepted: February 23, 2018

Online Published: March 1, 2018

doi:10.5539/ibr.v11n4p65

URL: https://doi.org/10.5539/ibr.v11n4p65

\begin{abstract}
The purpose of this paper is to investigate the capital structure of family firms in a context of crisis. Specifically, it aims to discover whether and how the determinants of their capital structure have a different impact on firms' leverage before and during the recent global financial crisis. Considering the pecking order theory (POT), trade-off theory (TOT), and agency theory (AT), this study analyzes 1,502 Italian medium family firms comparing the pre-crisis (2005-2007) and crisis (2008-2010) periods. This research shows that that current liquidity, asset structure, and agency costs are the most important variables in influencing medium family firms' leverage, in both the pre-crisis and crisis periods. Moreover, during the crisis, agency costs increase and have a negative influence on the short-term leverage highlighting that crisis contingencies influence the agency-based effects on family firm's leverage. Furthermore, our findings highlight that a more exhaustive understanding of family firms' capital structure can be achieved through the combined use of different theories.
\end{abstract}

Keywords: agency costs, capital structure, family firms, financial crisis

\section{Introduction}

Capital structure decisions are key factors for the development and survival of firms (Mahérault, 2004) and for the economic growth. Firms' decisions about debt or equity assumed great importance during the recent global financial crisis triggered in $2008^{1}$. This crisis produced important financial effects such as failure of banks and financial intermediaries, credit rationing, reduced investment and consumption, and a long downturn in the economic life cycle (Aiyar, 2015). This severe economic and financial context has influenced firms' financial behaviour, and thus understanding which factors influence firms' financial behavior has become increasingly relevant for management studies and policy makers.

Financial behavior of family firms - the most ubiquitous form of business organization in any world economy (La Porta et al., 1999) - has become a topic of growing interest because many research have highlighted that family firms' financial decision-making is unique and very different from non-family firms (Anderson et al., 2003; Koropp et al., 2013; Crespi \& Martin-Oliver, 2015; Steijvers \& Voordeckers, 2009; Wu et al., 2007). Family firms are strongly dependent on self-financing, and they often forgo growth opportunities due to their reluctance to issue external funds in order to safeguard family control (Croci et al., 2011; Gonzalez et al., 2013; Mahérault, 2004; Romano et al., 2000; Wu et al., 2007) and protect their socioemotional wealth (GomezMejìa et al., 2007). Family firms' financial choices appear to be the result of a trade-off between the need to increase debt for reducing the risk of losing control and the need for reducing debt to minimize the risk of failure (Gottardo \& Moisello, 2014).

Previous studies have improved our understanding of capital structure decisions of family firms, but they have provided only a partial explanation of family firms' financial behavior. To the best of our knowledge, and except for the study of Crespì and Martin-Oliver (2015) which compares family and non-family firms' ability to access

${ }^{1}$ For simplicity reasons, in this study, the term "crisis" and "global financial crisis" are used interchangeably. 
debt during the recent global financial crisis, previous research has studied family firms' financial behavior under normal market conditions (where risk and firms' performances are relatively stable). Then, we still little know about the effect of the global crisis on family firm's capital structure. However, several studies on non-family firms highlighted that capital structure may be sensitive to contextual factors (Antoniou et al., 2008; Venanzi \& Naccarato, 2017) and to an economic downturn (Antoniou et al., 2008; Danso \& Adomako, 2014; Frank \& Goyal, 2009; Micheales et al., 1999). In particular, recent studies (e.g. Danso \& Adomako, 2014; Van Hoang et al., 2018) have showed a strong empirical evidence of the effects of the recent financial crisis on firms' capital structure. Hence, we aim to address this knowledge gap in the field of family business by analyzing whether and how the determinants of family firms' leverage change their influence during the crisis. Specifically, we investigate crisis (2008-2010) and pre-crisis (2005-2007) periods for comparing the influence of the capital structure determinants on family firms' leverage. Following Myers (2001), who suggested that there is not yet a unique generally accepted perspective for explaining financial structure decisions, we refer to the most used capital structure theory, such as the pecking order theory (POT) (Myers, 1984; Myers \& Majluf, 1984), trade-off theory (TOT) (DeAngelo \& Masulius, 1980), and agency theory (AT) (Berle \& Means, 1932; Jensen et al., 1976), in order to analyze family firms' capital structure.

To test our hypotheses, we focus on a sample of 1,502 Italian medium family firms (unlisted). Italy is a very interesting environment in which to test capital structure choices of family firms; its industrial system is characterized by the prevalence of small and medium firms ( $85 \%$ of total firms) which are, on average, the most indebted in the EU (European Commission, SBA, Italy, 2013). Moreover, Italy is characterized by a banked-oriented financial system (with strong borrower-lender relationship) and an underdeveloped stock market with the dominance of unlisted firms, which are very different from listed companies in terms of their access to capital market (Crespì \& Martin-Oliver, 2015), and thus they could be differently affected by the financial crisis (Danso \& Adomako, 2014, p. 1171). Moreover, this study focuses only on medium sized family firms because differences between small and medium firms might arise regarding their preferences, risk aversions, bankruptcy, and abilities to access the debt (Chittenden et al., 1996; Cressy \& Olofsson, 1997; Köksal \& Orman, 2015).

Our results show that current liquidity, asset structure, and agency costs are the most important variables in influencing medium family firms' leverage, in both the pre-crisis and crisis periods. Moreover, during the crisis, agency costs increase and have a negative influence on the short-term leverage. Our findings also highlight that family firms have an order of preference between short-term and long-term debts as assumed by the POT; however, during the crisis, their short-term debt decreases whereas the long-term debt tends to increase.

Our study offers many contributions to the literature regarding the capital structure of family firms. First, it provides a more fine-grained understanding of capital structure determinants in family firms by expanding the knowledge on this topic in a context of crisis that has not been fully explored. Specifically, this study highlights that not all the most used variables of POT and TOT are relevant in explaining family firms' capital structure, and that during the crisis, the impact of capital structure determinants on firms' leverage is different from the pre-crisis period. This finding suggests that the explanatory ability of different theories depend on contingent factors, such as the economic cycle. Secondly, our study shows that no single theory can fully explain family firms' leverage and that a more accurate explanation of capital structure determinants of family firms can be achieved through the combined use of different theories. Finally, regarding the agency theory, our study contributes to better understand the contingencies that could influence the agency-based effects in family firms (Zahra, 2005).

The reminder of the paper is organized as follows: Section 2 reviews the literature on capital structure determinants in family firms referring to POT, TOT, and AT, and develops our hypotheses; Section 3 describes the dataset, sample selection criteria, variables, and descriptive statistics; Section 4 shows our regression models and results; finally, Section 5 presents the discussion and conclusion.

\section{Capital Structure and Its Determinants: Theoretical Frameworks and Hypothesis}

\subsection{Theoretical Frameworks for Family Firms' Capital Structure}

The literature on family firms' financial behavior points out that they follow a "peculiar financial logic" (Gallo et al., 2004, p. 315) characterized by the owner-manager's orientation with respect to risk, growth, ownership control, and the intention to protect the socioemotional wealth of family members (Gomez- Mejìa et al. 2007). Specifically, existing empirical research on family firms' capital structure has highlighted that: a) both economic and non-economic reasons influence their financial decisions (Gallo et al., 2004; Koropp et al. 2013); b) they are strongly dependent on self-financing and adopt conservative financial strategies (Romano et al., 2000); and c) they often forgo growth opportunities due to their reluctance in issuing new external resources to safeguard 
family control on the business (Croci et al., 2011; Gonzalez et al., 2013; Mahérault, 2004; Romano et al., 2000; $\mathrm{Wu}$ et al., 2007). However, these empirical studies on family firms have given mixed results about the main determinants of their capital structure (Coleman \& Carsky, 1999; Romano et al., 2000; Lopez-Garcia et al., 2007).

In our study, we refer to the most used theory (POT, TOT, and AT) to explain the capital structure of family firms. The market timing theory (Baker \&Wurgler; 2002) is not considered because family firms are typically privately held and are reluctant to raise external equity in order to maintain family control of the business (Croci et al., 2011; Romano et al., 2000).

The POT (Myers, 1984; Myers \& Majluf, 1984) considers the existence of asymmetric information between internal and external financiers; it suggests that companies usually adopt schematic processes and hierarchical choices among different funding sources. Specifically, firms will choose financing based on the following order of descending preference: internal funds, debt, and equity. This financial logic also reflects the objective of owners to maintain the control of the business and operational independence from external financiers. This theory is particularly appropriate to explain the debt-equity choice of family firms. Indeed, several studies have highlighted their reluctance to use debt or new external equity due to their intention to safeguard the family control on the business and protect the business for future generations (Croci et al., 2011; Gonzalez et al., 2013; Mahérault, 2004; Romano et al., 2000; Wu et al., 2007). Hence, family firms' financial behavior appears to fit with the POT framework (Poutziouris, 2001).

According to the TOT (Modigliani \& Miller, 1958, 1963), firms' financial choices are driven by the search of an optimal level of indebtedness; this optimal target is achieved by optimizing the trade-off between tax benefits associated with the debt and risks of failure caused by debt increase (DeAngelo et al., 1980). From this perspective, capital structure decisions are driven by the intention to balance the cost and benefits associated to the leverage. In particular, the TOT takes into account fiscal and financial distress issues in order to explain the debt-equity choices of firms: firms should prefer debt due to the tax deductibility of financial interests and if their higher size reduces the probability of bankruptcy. Existing research suggests that family firms would target their debt level to maintain the family control of the business. Moreover, other existing empirical research highlights that family firms seem to pursue indebtedness target ratio (Bauweraerts \& Colot, 2012) and can approach their debt target ratio more quickly than non-family firms (Lopez-Gracia \& Sanchez-Andujar,2007).

According to the AT (Berle \& Means, 1932; Jensen et al., 1976), agency costs are caused by information asymmetries and risk aversion, and they may arise when agents' behavior is not consistent with the principals' interest. In the literature, it is widely held that agency costs represent a key determinant of firms' capital structure (Jensen \& Meckling, 1976; Jensen, 1986). Indeed, the "free-cash flow" hypothesis (Jensen, 1986) points out the disciplinary role of debt in reducing the cash flow that may be used at the discretion of managers; this is due to the threat of liquidation or the pressure in generating cash flow to service the debt.

In the context of family firms, traditional agency theory assumes that the conflicts between shareholders and managers should be minimal, or not existent, due to their concentrated ownership and presence of owners-managers (Fama \& Jensen, 1983; Jensen et al., 1976). Following this perspective, when managerial ownership grows, interest in reducing risks leads to decrease the use of debt (Brailsford et al., 2002). Instead, when family owners are not involved in management, they may prefer to increase debt to reduce manager's opportunistic behaviors (Stulz, 1988). However, recent research has shown that family involvement in the business many lead to other kinds of agency problem (Anderson \& Reeb, 2003; Chrisman et al., 2004; Schulze et al., 2001, 2003a, 2003b; Villalonga \& Amit, 2006) engendered by self-control and altruism (Lubatkin et al., 2005). In addition, Blanco-Mazagatos et al., (2007) shows that family involvement across generations may determine agency conflicts which may influence family firm's capital structure choices. Consequently, we can assume that agency costs may also affect capital structure choices in family firms.

\subsection{Determinants of Family Firm's Capital Structure}

Empirical research has highlighted that the theoretical construct developed by the theories on capital structure need to be proxied indirectly by a set of firms' characteristics (Cassar \& Holmes, 2003, p. 127) (such as size, profitability, asset structure, growth, etc.). Moreover, the literature suggests that debt-equity choices are related to firms' characteristics which are specific for each firm (Proença et al., 2014), and that there is not yet a unique generally accepted perspective for explaining decisions on firms' financial structure (Myers, 2001). Consequently, the choice of appropriate explanatory variables of capital structure may be difficult and controversial (Harris \& Raviv, 1991; Titman \& Wessles, 1988). Taking into account these aspects, we consider that previous studies can help us in defining the most appropriate proxy variables needed in our study. Thus, we 
refer to those determinants most used in previous studies (e.g. Kumar et al., 2017; Rajan \& Zingales, 1995) and we give particular attention to previous empirical research on capital structure determinants in family, unlisted, and small and medium firms (e.g. Ampenberger et al., 2013; Cassar \& Holmes, 2003; Coleman \& Carsky, 1999; González et al., 2013; Gottardo and Moisello, 2014; Lopez-Gracia \& Sánchez-Andùjar, 2007). Following this literature, we indentified the most commonly adopted determinants of medium family firms' capital structure as follows: firm size, firm age, profitability, asset structure, and current liquidity. Moreover, from the perspective of the agency theory, we extend the traditional proxies of agency costs, which have been tested in non-family firms, to the field of family firms due to the absence, to date, of specific operational measure developed for family firms' agency costs. This selecting variable approach allows us better identifying the possible capital structure determinants of medium family firms and comparing our results with other existing empirical research on capital structure of family firms.

We investigate the relationship between these selected determinants and the capital structure of family firms comparing the pre-crisis and crisis periods. Specifically, we select the most severe period of crisis which affected the Italian economy (2008-2010) (European Commission, SBA Italy, 2014), and compare it with the pre-crisis period (2005-2007). The financial crisis (started in 2008) generated a long period of economic recession in Italy, as in many other European countries (Berkowitz et al. 2015). This context was characterized by an increase of uncertainty and instability of market with a consequent uncertainty and decline in long-term investments (Demirguc-Kunt et al. 2015). This financial and economic turbulence had important effects on the Italian banking system. In particular, the cost of capital increased, and the criteria adopted for the loans to businesses became more stringent (Banca d'Italia, 2010). Moreover, the economic recession reduced the level of turnover and profits of many businesses in manufactory industry (Centro Studi Confindustria, 2008) limiting their ability to self-financing.

Consequently, these conditions could modify the influence of capital structures determinants in family firms. Indeed, family firms' owners generally adopt conservative financial strategies and use a mix of personal and internal funds instead of external resources (Koropp et al., 2014; Poutziouris, 2001). They consider companies as an asset for future generations, and this is emphasized, during the crisis, when the risk of failure and loss of control are high. Effectively, they follow reasons related to family concerns rather than economic and financial logic (Koropp et al., 2014). Nevertheless, an internal financial strategy may be difficult to pursue during a crisis due to the decrease in profitability and liquidity, which are key factors in influencing the financial behavior of family firms (Blanco-Mazagatos et al., 2007; Koropp et al., 2014). This contingency should push family firms to use more external financial resources during the crisis period, but this financial strategy could be obstructed by the credit rationing in the capital market

Based on such consideration, we expect that crisis influence capitals structure choices of family firms, and thus the determinants of family firms' leverage may change their influence (degrees of influence, significance or sign) during the crisis period compared to non-crisis period.

\subsection{Hypotheses Development}

Age

The number of years since the business was founded can influence firms' capital structure (Coleman \& Carski, 1999; Romano et al., 2000). According to the POT, the greater the age of firms, the greater the chance that over time firms have accumulated and saved funds reducing its resorting to debt (Coleman \& Carski, 199; López-Gracia \& Andùjar, 2007). Existing research has shown variations in this relationship among different countries, and particularly, the existence of a negative association between age and leverage in Italian SMEs (Hall et al., 2004). The argumentations proposed by the POT are also relevant in a context of crisis due to the credit rationing. Then, we formulate the following hypotheses:

H1a: During non-crisis period, family firm's age is negatively related to leverage.

H1b: During crisis period, family firm's age is negatively related to leverage.

\section{Size}

From the TOT perspective, some studies suggest the existence of a positive relationship between firm size and debt due to the more diversification and then less risk of financial distress of large firms (Rajan \& Zingales, 1995). On the other hand, the POT predicts the existence of a negative relationship because larger firms face lower adverse selection and then can more easily resort in issuing new capital (Köksal \& Orman, 2015). Existing empirical research on medium family firm highlights the existence of a negative relationship between size and leverage (e.g. Gottardo \& Moisello, 2014). Indeed, in family firms, the increase in size can enlarge their ability 
to generate internal resources, supporting their self-financing logic (above described). Moreover, Anderson and Reeb (2003) have shown that family firms have less need to engage in corporate diversification to reduce firm risk. Family firms reduce the business risk using financing forms with low probabilities of default, and specifically preferring equity (Anderson \& Reeb, 2003, p. 656-657). Thus, the proposition of the TOT does not seem to describe well the financial behavior of family firms.

During the crisis, the larger the size of firms, the greater the ability to cope with its effects (such as the reduction in revenues and profitability, and the uncertainty of the marked). Indeed, larger firms may have more internal resources or accumulated funds and more tangible assets that can be used as collaterals to access the debt. Therefore, we formulate the following hypotheses:

H2a: During non-crisis period, family firm's size is negatively related to leverage.

$\mathrm{H} 2 \mathrm{~b}$ : During crisis period, family firm's size is negatively related to leverage.

\section{Profitability}

According to the TOT, there is a positive relationship between firms' profitability and leverage due to the lower risk of default and need to offset corporate tax. On the other hand, the POT predicts the existence of a negative relationship between profitability and leverage, as profitable firms can use retained earnings to finance their investments rather than employing debt. The literature regarding family firms highlights that profitability is a key factor in influencing their financial behavior (Blanco-Mazagatos et al., 2007; Koropp et al., 2014) due to their peculiar financial logic. Indeed, high profitability can support their financial strategies based on self-financing (as described above). Existing research on family firms' capital structure (in non-crisis period) supports the existence of a negative relationship between firms' profitability and debt (Croci et al., 2011; López-Gracia \& Andùjar, 2007; Santos et al., 2014).

During the crisis, the higher information asymmetries between investors and managers (Mishkin, 1991, 1992) can strengthen the preference in using internal financial resources. Moreover, empirical studies on capital structure of small and medium firms during crisis confirm the existence of a negative relationship between profitability and debt level (Balios et al., 2015; Proença et al., 2014), and also for medium family firms (Gottardo \& Moisello, 2014). Hence, we formulate the following hypotheses:

H3a: During non-crisis period, family firm's profitability is negatively related to leverage.

H3b: During crisis period, family firm's profitability is negatively related to leverage.

Asset structure (tangible asset)

Many empirical researches have generally shown a positive relationship between asset tangibility and firms' leverage (Chittenden et al. 1996; Michaelas et al., 1999; Van der Vijist \& Thurik, 1993). This positive association is due to the fact that tangible assets can be used as a collateral for a easier access to debt (long term debt) (Frank \& Goyal, 2009), despite the POT assumes a negative relationships because the low information asymmetries related to tangible assets make more convenient the use of new equity (Harris \& Raviv 1991; Kösal \& Orman, 2015). Empirical research on family firms' capital structure shows a positive association between tangible asset and leverage (Amperberg et al., 2013; Gottardo \& Moisello, 2014).

During crisis period, the use of tangible assets as collateral may be critical due to the market uncertainty and the increase of asymmetries information between borrowers and lenders. However, previous studies on capital structure of small and medium firms in a context of crisis show the existence of a negative association between tangible assets and leverage, especially with long-term leverage (Balios et al., 2016; Muijs, 2015; Proença et al., 2014). Moreover, for family firms, the use of tangible assets as collateral for new debt may create a strong exposure of family assets due to the close overlap of family members' wealth and the business. The uncertainty and risk related to the crisis may increase this risk for family firms, and thus they may be reluctant to use tangible assets as collateral due to their fear of losing shareholding rights and discretion to act in favor of the non-family investor. Hence, we formulate the following hypotheses:

H4a: During non-crisis period, family firm's asset structure is positively related to leverage.

H4b: During crisis period, family firm's asset structure is negatively related to leverage.

\section{Current liquidity}

Existing research suggests that firms with higher liquidity use them to finance its investments (Ozkan, 2001). Indeed, according to the POT, an increase in current liquidity reduces the need to resort to debt, and thus a negative relationship between current liquidity and firms' leverage is expected. Moreover, current liquidity ratio 
can measure the short-term solvency of a firm. Indeed, a low level of liquidity may indicate a low capacity of a firm to cope with its debts, and therefore a firm with low liquidity can be seen by external lenders as a firm with greater potential of default (Proença et al., 2014). Previous studies on the capital structure of family firms have highlighted the existence of a negative relationship between current liquidity and leverage (Anderson and Reeb, 2003; Croci et al., 2011; Gottardo \& Moisello, 2014); in effect, this is supported by the argumentations of family firms' preference for the use of internal resources compared to the use of debt.

During a crisis period, firms may have difficulty in reaching high levels of liquidity as debtors can delay payments due to the decline in sales, profitability, and credit rationing. Consequently, firms' capacity to meet their debt obligations on time may decrease reducing the ability to access additional debt. Then, we formulate the following hypotheses:

H5a: During non-crisis period, family firm's current liquidity is negatively related to leverage.

H5b: During crisis period, family firm's current liquidity is negatively related to leverage.

Agency costs

Existing research highlights that, in family firms, there is more use of debt when agency conflicts between ownership and management increase because of altruism problem (Blanco-Mazagatos et al., 2015). In particular, when agency costs increase there is an enlargement of firms' capital structure following a peaking order in funding preference. Thus, we expect that, in non-crisis period, an increase of agency costs should lead to an increase in the use of debt.

During a crisis, the dynamics of agency conflicts may change due to the uncertainty and more risk aversion. In family firms, the risk of failure represents a personal failure for family owners, including the risk of losing everything (Gallo et al., 1996). Then, family owners may forgo the temptation to expropriate resources (Attig et al., 2015) transferring losses on minority shareholders or conversely to assist firms with their personal resources (Friedmam et al., 2003). This behavior can produce agency conflicts between family and non-family shareholders, and non-family managers, which instead may prefer to invest in risky projects because they could enjoy the benefits, without suffering the risk of failure. Thus, we hypothesize that agency costs should increase during the crisis. High agency conflicts may lead to an increase in leverage to discipline the discretional behavior of management; however, a high leverage, during the crisis period, could even amplify the probability of bankruptcy of firms, and thus family owners may prefer acting cautious and do not increase firms' leverage. Therefore, we formulate the following hypothesis:

H6a: During non-crisis period, agency costs have a positive influence on family firm's leverage.

H6b: During crisis period, agency costs have a negative influence on family firm's leverage.

\section{Data}

\subsection{Dataset}

Our data are gathered from the AIDA database that is the Italian provider of the Bureau Van Dijk European Database. It contains detailed information with up to ten years of history of approximately 1,170,000 Italian listed and non-listed companies. We select only medium firms and follow the European Commission (2005) definition. According to this criterion, a firm is considered as "medium" if it satisfies simultaneously the following characteristics: 1) turnover less than, or equal to, $€ 50$ million (or total assets less than, or equal to, $€$ 43 million); 2) number of employees less than, or equal to, 250 units; and 3) not classified as "small" enterprises (simultaneously less than 50 employees and turnover less than, or equal to, $€ 10$ million, or total assets less than, or equal to, $€ 10$ million). To meet this definition, we choose only those companies that maintained this status for the whole period. In addition, we focus only on medium family firms with the following features: a) unlisted limited, limited liability or companies limited by share; b) operating in the manufacturing industry (classes 10-30 of ATECO code); and c) not included in a bankruptcy process.

We consider only firms operating in manufacturing industry because: a) they represent about $40 \%$ of medium Italian firms (ISTAT, 2011); b) companies in this sector have a capital structure that differs from other sectors (Köksal \& Orman, 2015; Romano et al., 2000; Tse \& Rodgers, 2014) and c) firms of the same industry are more similar according to their capital structure (Romano et al., 2000). The above criteria provide a sample of 1,841 firms. To select family firms, we verify whether firms were family owned by multiple family members of the same family (the majority of equity owned by the family) (Miller et al., 2008; Zahra, 2005). We also adopt the "surname" criterion and verify the uncertain cases (50.01\% of equity owned by persons with different surnames) using the balance sheets documents taken from the Chambers of Commerce. The doubtful cases, despite this 
additional control, are not considered; furthermore, companies without all data available for the multivariate analysis are excluded. After this selection, a final sample of 1,502 firms across six years is available for the analysis.

\subsection{Variables Description}

We investigate family firms' capital structure adopting three different measures: the total leverage (TDL $=$ total debt/total asset), long-term leverage (LTL = long-term debt/total asset), and short-term leverage $(\mathrm{STL}=$ short-term debt/total asset). The decomposition of leverage is appropriate because Italian SMEs are characterized by a strong preference for the short-term debt; hence, the use of a single index may hide the differences between short and long-term leverage (Chittenden et al., 1996; Van de Wijst \& Thurik, 1993). Furthermore, the ratio on total asset is more appropriately than using liabilities because the former better explains the risk of firm default (Michaelas et al., 1999; Rajan \& Zingales, 1995). The dependent variables are considered at 2007, for the pre-crisis period, and at 2010 , for the crisis, respectively.

The independent variables used in our study are summarized in Table 1. Following Singh and Davidson (2003), and Ang et al. (2000), for agency costs, we consider asset utilization and discretionary expenses as proxies. The former is the ratio of annual sales to total assets and captures the inefficient utilization of assets due to opportunistic management behavior, or to poor monitoring systems. Thus, we stress that the asset utilization ratio is inversely related to the level of agency conflicts. The latter is the ratio of discretionary operating expenses to total sales. It assesses the efficiency of operating costs management; hence, it could be a signal that agents expropriate shareholder's wealth for personal perquisite consumption, or inefficient investments. Thus, the ratio of discretionary operating expenses is directly related to the level of agency costs.

The independent variables are collected a time $\mathrm{t}-1$ with respect to the dependent variables; specifically, they are averages of their values at 2005 and 2006 for considering the whole pre-crisis period, and at 2008 and 2009 for taking into account the crisis, respectively.

Starting from the predictors introduced in Section 2.3, we proceed to the selection of the final set of independent variables using the "backward elimination" criteria (Sparks et al., 1985). However, we also tested the stepwise regression, based on the AIC criterion, and it led to the same results. Differently from other research findings, profitability is not significant in our analysis, neither before, neither during the crisis. Moreover, the insertion of this variable in our models brings to worse performance in term of explained variability and AIC. Thus, PROFIT has been deleted from our final models. Based on the above criteria, we refer to a logarithmic transformation of both dependent and independent variables.

Table I. Variables Description

\begin{tabular}{|c|c|c|c|}
\hline Variables & Abbreviation & Measure & Literature \\
\hline Leverage & $\begin{array}{l}\text { TDL } \\
\text { STD } \\
\text { LTD }\end{array}$ & $\begin{array}{l}\text { total debt/total asset } \\
\text { short-term debt/total asset } \\
\text { long-term debt/total asset }\end{array}$ & $\begin{array}{l}\text { Kösal \& Orman (2015); Rajan \& } \\
\text { Zingales (1995); Michaelas et al. } \\
\text { (1999) }\end{array}$ \\
\hline Size & $\begin{array}{l}\text { EMPL } \\
\text { SALES }\end{array}$ & $\begin{array}{l}\text { the number of employees } \\
\text { sales }\end{array}$ & Köksal \& Orman (2015) \\
\hline Age & AGE & $\begin{array}{l}\text { the number of years since the company has } \\
\text { been founded }\end{array}$ & Mac an Bhaird \& Lucey (2010) \\
\hline Profitability & PROFIT & earnings before interest and tax/total asset & Degryse et al. (2012) \\
\hline Asset structure & A_STURC & tangible assets/total asset & Cassar \& Holmes (2003) \\
\hline Current liquidity & CUR_LIQ & current asset/current liabilities & Mateev et al., 2013 \\
\hline Agency costs & $\begin{array}{l}\text { AUR } \\
\text { DER }\end{array}$ & $\begin{array}{l}\text { annual sales/ total asset } \\
\text { discretionary operating expenses/total sales }\end{array}$ & $\begin{array}{l}\text { Singh \& Davidson (2003); } \\
\text { Ang et al. (2000) }\end{array}$ \\
\hline
\end{tabular}

\subsection{Descriptive Statistics}

Table II shows the descriptive statistics of the variables; it highlights that TDL and STL decrease, on average, from the pre-crisis to the crisis period, while LTL increases. We observe that family firms prefer STL rather than LTL. CUR_LIQ does not undergo a large variation from the first to the second period, but its standard deviation strongly increases. In contrast, SALES decreases, on average, from 17,954,290 to 17,526,648 euro. A_STURC shows an increase of 0.071 from the pre-crisis period to the crisis. AUR decreases slightly during the crisis, while DER does not significantly change, thus, agency costs increase; however, their standard deviations largely decrease, indicating that family firms' behavior, during the crisis, is homogeneous with respect to this agency cost. 
Table II. Descriptive statistics

\begin{tabular}{|c|c|c|c|c|}
\hline Variables & Min & $\operatorname{Max}$ & Mean & $\mathrm{Sd}$ \\
\hline \multicolumn{5}{|c|}{ Explanatory Variables for POT } \\
\hline AGE & 2 & 99 & 28.92 & 14.85 \\
\hline \multicolumn{5}{|c|}{ Explanatory Variables for POT and TOT } \\
\hline EMPL & 3 & 236 & 71.94 & 40.11 \\
\hline SALES PRE CRISIS & 3,870 & 78,811 & 17,954 & 9,107 \\
\hline SALES CRISIS & 3,449 & 86,684 & 17,526 & 9,391 \\
\hline A_STURC PRE CRISIS & 0.0108 & 0.7935 & 0.2201 & 0.1361 \\
\hline A_STURC CRISIS & 0.0077 & 0.8445 & 0.2916 & 0.1663 \\
\hline CUR LIQ PRE CRISIS & 0.2700 & 3.7950 & 1.0420 & 0.4626 \\
\hline CUR LIQ CRISIS & 0.2450 & 5.4450 & 1.0962 & 0.5704 \\
\hline \multicolumn{5}{|c|}{ Explanatory Variables for $A T$} \\
\hline AUR PRE CRISIS & 0.3965 & 3.5190 & 1.2567 & 0.4427 \\
\hline AUR CRISIS & 0.7859 & 1.2014 & 0.9750 & 0.0483 \\
\hline DER PRE CRISIS & 0.1865 & 3.5274 & 1.1014 & 0.4588 \\
\hline DER CRISIS & 0.7786 & 1.3985 & 1.0479 & 0.1085 \\
\hline \multicolumn{5}{|l|}{ Dependent Variables } \\
\hline TDL PRE CRISIS & 0.1754 & 0.9664 & 0.6445 & 0.1701 \\
\hline TDL CRISIS & 0.1253 & 0.9575 & 0.5658 & 0.1827 \\
\hline STL PRE CRISIS & 0.1604 & 0.9671 & 0.5456 & 0.1623 \\
\hline STL CRISIS & 0.0935 & 0.9336 & 0.4515 & 0.1704 \\
\hline LTL PRE CRISIS & 0.0000 & 0.5826 & 0.0989 & 0.0982 \\
\hline LTL CRISIS & 0.0000 & 0.5401 & 0.1143 & 0.1024 \\
\hline
\end{tabular}

Notes. Values in 000/euro. $\mathrm{N}=1,502$ family firms.

Table III displays the correlation matrix; it shows that the leverage is influenced by: age (AGE), employee (EMPL), sales (SALES), current liquidity (CUR_LIQ), asset structure (A_STURC), asset utilization ratio (AUR), and discretionary operating expenses ratio (DER). Specifically, CUR_LIQ has high correlations with TDL $(-0.717$ before the pre-crisis, and -0.695 during the crisis) and STL $(-0.673$ before the pre-crisis, and -0.619 during the crisis). EMPL, AGE, and A_STURC are negatively correlated with TDL and STL, in both periods. The variables AUR and DER, before the crisis, show positive correlations with TDL and STL; however, during the crisis, the correlation between AUR and, both TDL and STL, increases, while the correlation between DER and, both TDL and STL, decreases. Instead, SALES is slightly positively correlated with TDL and STL, in both periods. The first empirical evidence is that the correlation, between the independent variables and TDL, are influenced by STL (short-period component of TDL). Indeed, neither the variables usually considered by POT and TOT, neither the agency costs, are correlated with LTL; only AUR, DER, and SALES, during the crisis, are lightly correlated with LTL. This lack of correlation certainly would deserve further investigation in future research regarding the capital structure of family firms. 
Table III. Correlation matrix of the transformed variables pre-crisis and during the crisis

\begin{tabular}{|c|c|c|c|c|c|c|c|c|c|c|}
\hline \multicolumn{11}{|c|}{ Pre-crisis } \\
\hline & TDL & STL & LTL & AGE & EMPL & CUR LIQ & SALES & A_STURC & AUR & DER \\
\hline \multicolumn{11}{|l|}{ TDL } \\
\hline STL & $.838 * *$ & & & & & & & & & \\
\hline LTL & $.055^{*}$ & -.043 & & & & & & & & \\
\hline AGE & $-.189 * *$ & $-.177 * *$ & -.022 & & & & & & & \\
\hline EMPL & $-.177 * *$ & $-.229 * *$ & -.036 & $.152 * *$ & & & & & & \\
\hline CUR LIQ & $-.717 * *$ & $-.673 * *$ & -.019 & $.087 * *$ & .014 & & & & & \\
\hline SALES & $.131 * *$ & $.123 * *$ & -.023 & $.062 *$ & $.159 * *$ & -.044 & & & & \\
\hline A_STURC & $-.057 *$ & $-.242 * *$ & .028 & $.095 * *$ & $.173 * *$ & $-.185 * *$ & $-.12 * *$ & & & \\
\hline AUR & $.142 * *$ & $.334 * *$ & -.036 & $-.12 * *$ & $-.28 * *$ & $.091 * *$ & $.168 * *$ & $-.253 * *$ & & \\
\hline DER & $.303 * *$ & $.258 * *$ & -.007 & .049 & .014 & $-.334 * *$ & .027 & .035 & $-.088 * *$ & \\
\hline \multicolumn{11}{|c|}{ During the crisis } \\
\hline & TDL & STL & LTL & AGE & EMPL & CUR LIQ & SALES & A_STURC & AUR & DER \\
\hline \multicolumn{11}{|l|}{ TDL } \\
\hline STL & $.836 * *$ & & & & & & & & & \\
\hline LTL & $.076^{* *}$ & $-.089 * *$ & & & & & & & & \\
\hline AGE & $-.192 * *$ & $-.208 * *$ & -.028 & & & & & & & \\
\hline EMPL & $-.148 * *$ & $-.223 * *$ & .015 & $.152 * *$ & & & & & & \\
\hline CUR LIQ & $-.695 * *$ & $-.619 * *$ & -.003 & $.087 * *$ & -.010 & & & & & \\
\hline SALES & $.160 * *$ & $.183 * *$ & $-.083 * *$ & $.051 *$ & $.066^{*}$ & -.013 & & & & \\
\hline A_STURC & $-.151 * *$ & $-.327 * *$ & -.024 & $.133 * *$ & $.161 * *$ & $-.207 * *$ & $-.113 * *$ & & & \\
\hline $\mathbf{A} \overline{\mathbf{U}} \mathbf{R}$ & $.193 * *$ & $.407 * *$ & $-.093 * *$ & $-.14 * *$ & $-.30 * *$ & $.146^{* *}$ & $.230 * *$ & $-.379 * *$ & & \\
\hline DER & $.075^{* *}$ & .002 & $.055^{*}$ & -.023 & $.082 * *$ & $-.101 * *$ & $-.106 * *$ & .024 & $-.082 * *$ & \\
\hline
\end{tabular}

Notes. ** Significance codes $0.01 ; *$ Significance codes 0.05 . Explanatory Variables for Capital Structure Theories:

-AGE as a proxy for POT.

-EMPL, SALES, A_STRUC, and CUR_LIQ as proxies for both TOT and POT.

-AUR and DER as proxies for AT.

\section{Method and Results}

\subsection{Regression Models and Hypotheses Check}

We consider six regression models to consider pre-crisis and crisis periods and the leverage decompositions. In models 1 and 2 the dependent variable is TDL, in the models 3 and 4 the dependent variable is STL, and finally in models 5 and 6, we consider LTL. The ordinary least squares method (OLS) is used to estimate the unknown parameters of the linear regression models using the $\mathrm{R}$ statistical software. The model takes the form:

$$
\ln Y=B_{0}+B_{1} \ln A G E+B_{2} \operatorname{lnEMPL}+B_{3} \ln A_{-} \_S T U R C++B_{4} \ln S A L E S+B_{5} \operatorname{lnCUR} \_L I Q+B_{6} \ln A U R+B_{7} \ln D E R+u
$$

We stress that models 5 and 6 show a very low relevance. Indeed, the coefficients of the LTL models are not statistically significant, except for few values during the crisis. In addition, the R-squared is very low, and thus the variables explaining STL and TDL do not explain at all the LTL. The residual plots (not inserted in this article) of the LTL models show the presence of two distinct groups, due to the presence of a considerable number of firms that do not use the long-term debt; in effect, we observed that the percentage of companies using consistently the long-term debt is very low. Even considering only these companies, it was not possible to identify predictors explaining the long-term debt. For these reasons, we discard models 5 and 6 (omitted) and concentrate only on models 1 and 2 (see Table IV) and models 3 and 4 (see Table V).

Our results suggest that AGE has a negative effect on family firms leverage both pre-crisis and during the crisis. This finding holds for both TDL and STL (see Tables IV and V) confirming hypotheses H1a and H1b.

Regarding the relationship between SIZE and leverage (see hypotheses $\mathrm{H} 2 \mathrm{a}$ and $\mathrm{H} 2 \mathrm{~b}$ ), our results suggest that, when SIZE is measured by EMPL, it has a negative effect on leverage, both before and during the crisis, confirming hypotheses H2a and H2b (both for TDL and STL). Contrary, if SIZE is expressed by SALES, it has a positive impact on leverage; however, it not statistically significant on STL in pre-crisis period (see Table V). In the latter circumstance, we underline that hypotheses $\mathrm{H} 2 \mathrm{a}$ and $\mathrm{H} 2 \mathrm{~b}$ should be rejected.

Because PROFIT is not statistically significant in explaining family firms' leverage, we have not considered it in our models as explained in Section 2.2. Thus, there is enough evidence, for rejecting both hypotheses H3a and $\mathrm{H} 3 \mathrm{~b}$. 
Tables IV and V highlight that A_STURC has always a significant negative effect on leverage. Therefore, hypothesis $\mathrm{H} 4 \mathrm{a}$ should be rejected because it suggests the existence of a positive relationship. Contrary, hypothesis $\mathrm{H} 4 \mathrm{~b}$ confirms that tangible assets negatively influence family firms' leverage during the crisis.

Our findings show that CUR_LIQ has always a negative effect on family firms leverage both pre-crisis and during the crisis. This confirms that, for both TDL and STL, current liquidity reduces the need to resort to debt confirming hypotheses $\mathrm{H} 5 \mathrm{a}$ and $\mathrm{H} 5 \mathrm{~b}$.

We observe that the two types of agency costs have opposite effects. Specifically, AUR has always a positive effect on leverage, and thus, because it is inversely proportional to agency costs, we can state that, if agency costs are expressed by AUR, hypothesis H6a is rejected and hypothesis H6b may be accepted. However, focusing our attention on DER, we observe different results. Indeed, Tables IV and V underline that DER has always a positive effect on leverage except for the STL model during the crisis. Therefore, we can accept hypothesis H6a and reject hypothesis H6b. Hence, the two proxies for agency costs for STL give conflicting results in the pre-crisis period, and thus we need to refer to their percentage contribution (see Section 3.2). This further analysis will be added to understand which the strongest effect between these two indicators is.

Table IV. Regression models for TDL pre-crisis and during the crisis

\begin{tabular}{|c|c|c|c|c|}
\hline \multicolumn{5}{|c|}{ MODEL $\mathbf{N}^{\circ} 1$ - TOTAL LEVERAGE PRE-CRISIS } \\
\hline VARIABLES & COEFF. & STD. ERROR & P-VALUE & VIF \\
\hline CONSTANT & -.751 & .106 & $.000 * * *$ & \\
\hline \multicolumn{5}{|c|}{ Explanatory Variables for POT } \\
\hline AGE & -.050 & .009 & $.000 * * *$ & 1.059 \\
\hline \multicolumn{5}{|c|}{ Explanatory Variables for POT and TOT } \\
\hline EMPL & -.054 & .009 & $.000 * * *$ & 1.180 \\
\hline CUR_LIQ & -.541 & .014 & $.000 * * *$ & 1.198 \\
\hline SALES & .056 & .011 & $.000 * * *$ & 1.110 \\
\hline A_STURC & -.048 & .007 & $.000 * * *$ & 1.142 \\
\hline \multicolumn{5}{|c|}{ Explanatory Variables for AT } \\
\hline AUR & .116 & .017 & $.000 * * *$ & 1.213 \\
\hline DER & .534 & .108 & $.000 * * *$ & 1.139 \\
\hline
\end{tabular}

Res. SE:0.1948 on 1494 DF $-R^{2}: 0.6078$. Adj. $R^{2}: 0.6059$ - F-stat.:330.7 on 7 and 1494 DF. $p$-val.: $<2.2 e-16$

\begin{tabular}{|c|c|c|c|c|}
\hline \multicolumn{5}{|c|}{ MODEL N’2 - TOTAL LEVERAGE DURING THE CRISIS } \\
\hline VARIABLES & COEFF. & STD. ERROR & P-VALUE & VIF \\
\hline CONSTANT & -1.218 & .125 & $.000 * * *$ & \\
\hline \multicolumn{5}{|c|}{ Explanatory Variables for POT } \\
\hline AGE & -.046 & .011 & $.000 * * *$ & 1.064 \\
\hline \multicolumn{5}{|c|}{ Explanatory Variables for POT and TOT } \\
\hline EMPL & -.041 & .010 & $.000 * * *$ & 1.154 \\
\hline CUR_LIQ & -.623 & .014 & $.000 * * *$ & 1.085 \\
\hline SALES & .075 & .013 & $.000 * * *$ & 1.104 \\
\hline A_STURC & -.102 & .008 & $.000 * * *$ & 1.222 \\
\hline \multicolumn{5}{|c|}{ Explanatory Variables for $A T$} \\
\hline AUR & .169 & .018 & $.000 * * *$ & 1.360 \\
\hline DER & .125 & .061 & .040 & 1.032 \\
\hline
\end{tabular}

Res. SE:0.2019 on 1494 DF - $R^{2}: 0.5787$. Adj. $R^{2}: 0.5768$ - F-stat.: 293.2 on 7 and 1494 DF. $\quad p$-val.: $<2.2 e-16$

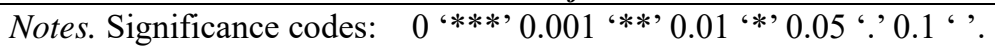

The log-log model is particularly suitable to interpret variables that are expressed as a percentage. The regression coefficients indicate the elasticity of the dependent variable with respect to the independent variable that is, the percentage change of leverage associated with a variation of a percentage point of the regressor. 
Table V. Regression models for STL pre-crisis and during the crisis

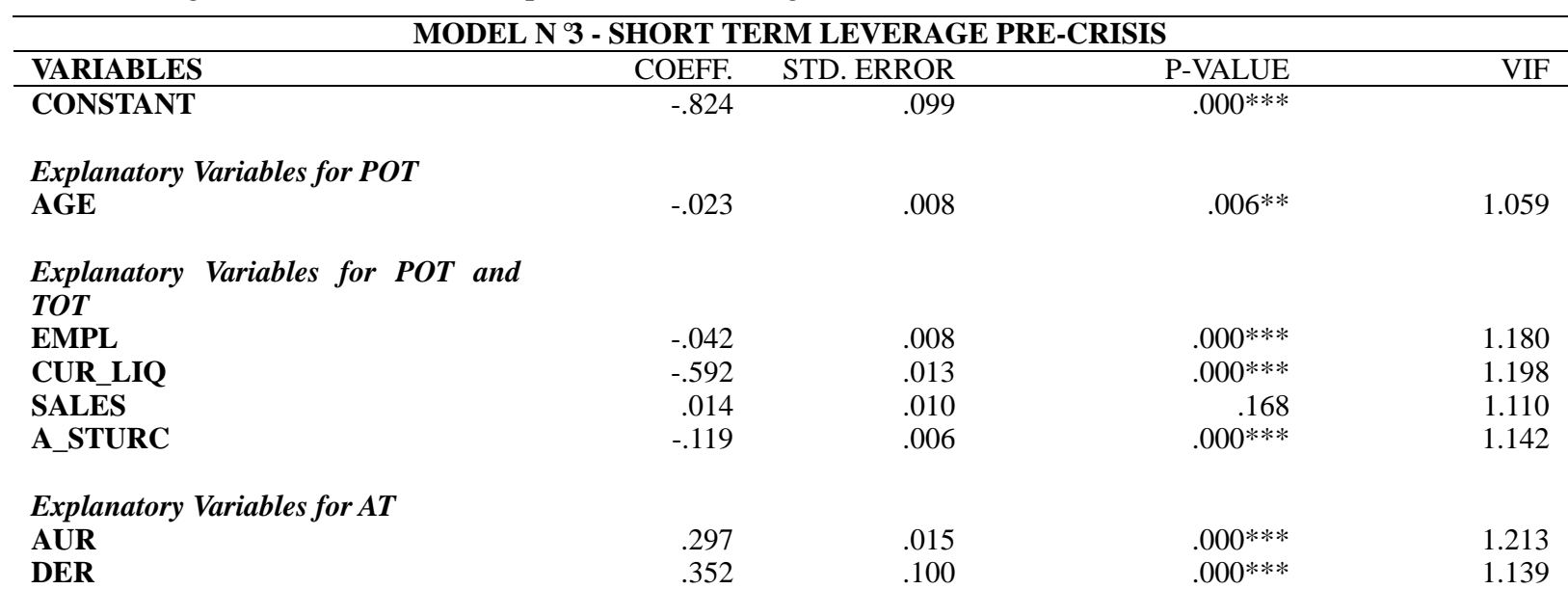

Res. SE: 0.1806 on $1494 \mathrm{DF}-R^{2}: 0.7021$. Adj. $R^{2}: 0.7007$ - F-stat.: 502.9 on 7 and 1494 DF. $\quad p$-val.: $<2.2 e-16$

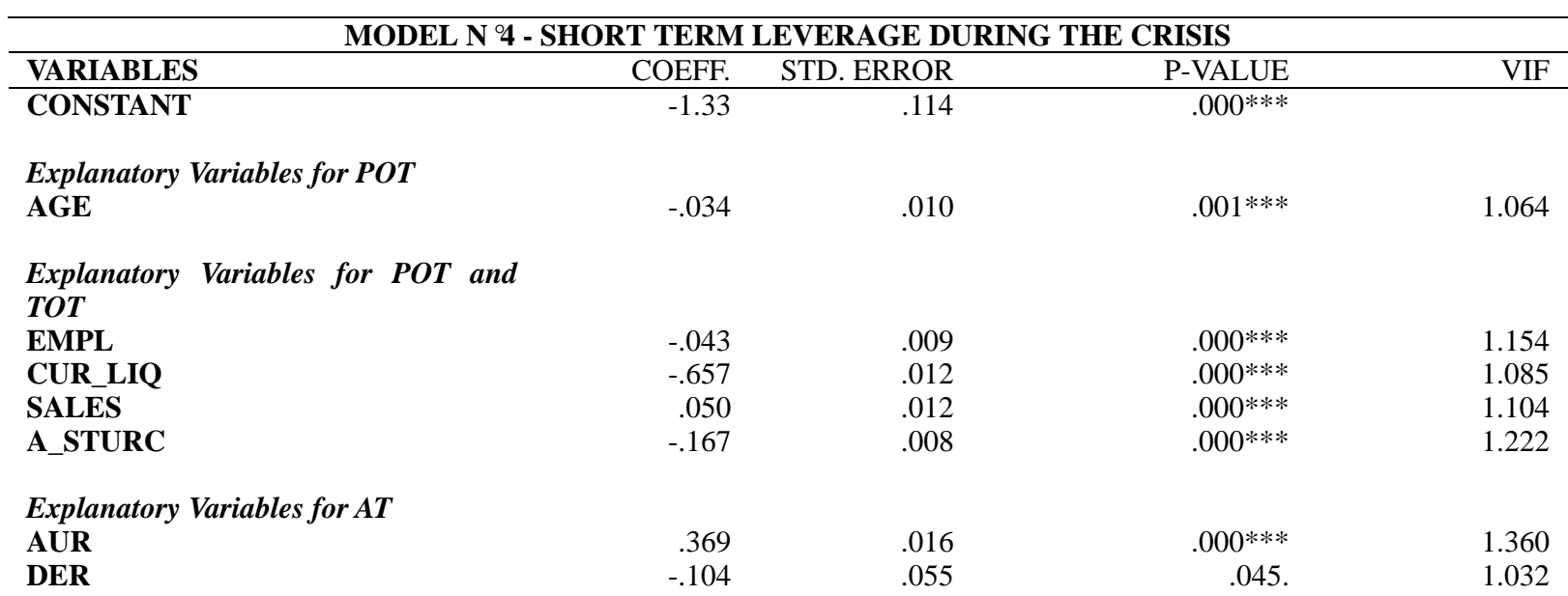

Res. SE:0.2145 on 1494 DF - $R^{2}: 0.7382$. Adj. $R^{2}: 0.737$ - F-stat.: 601.8 on 7 and 1494 DF. p-val.: $<2.2 e-16$

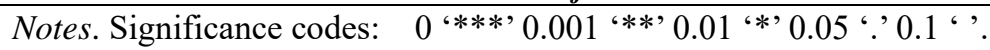

\subsection{The Effect Dimension}

Our results suggest that the capital structure determinants, in the medium Italian family firms, have different degrees of influence on leverage before and during the crisis. Moreover, some predictors such agency costs are composed by different proxies providing conflicting results. For these reasons, we introduce the "dimension of the effect" of each variable (Chiorri, 2010) that is the percentage contribution in influencing the dependent variable (Courville and Thompson, 2001): $\mathrm{f}^{2}=\left(\mathrm{R}^{2}-\mathrm{R}_{\mathrm{k}-1}^{2}\right) /\left(1-\mathrm{R}^{2}\right)$, where $\mathrm{f}^{2}{ }_{\mathrm{i}}$ is the dimension of the effect of the $\mathrm{i}-\mathrm{th}$ variable in explaining the dependent variable, and $\mathrm{R}_{\mathrm{k}-1}$ is the R-squared of the model computed without the variable $\mathrm{i}-\mathrm{th}$. Because variables are not expressed in the same units, we refer to standardized coefficients. Table VI shows the percentage contribution of each variable in explaining leverage for both periods. 
Table VI. Percentage contribution in influencing TDL and STL pre-crisis and during the crisis periods

\begin{tabular}{|c|c|c|c|c|c|c|c|c|}
\hline & \multicolumn{2}{|c|}{ TDL } & \multicolumn{2}{|c|}{$\begin{array}{c}\text { Difference between } \\
\text { regression } \\
\text { coefficients }\end{array}$} & \multicolumn{2}{|c|}{ STL } & \multicolumn{2}{|c|}{$\begin{array}{l}\text { Difference between } \\
\text { regression coefficients }\end{array}$} \\
\hline & pre-crisis & crisis & $\mathrm{T}$ & P-value & pre-crisis & crisis & $\mathrm{T}$ & P-value \\
\hline \multicolumn{9}{|l|}{ Exp. for POT } \\
\hline AGE & $2.85 \%$ & $2.07 \%$ & 0.28 & 0.77 & $1.01 \%$ & $1.30 \%$ & 0.85 & 0.39 \\
\hline \multicolumn{9}{|l|}{$\begin{array}{r}\text { Exp. for POT } \\
\text { and TOT }\end{array}$} \\
\hline EMPL & $3.26 \%$ & $1.59 \%$ & 0.96 & 0.33 & $2.65 \%$ & $1.99 \%$ & 0.08 & 0.93 \\
\hline CUR_LIQ & $83.73 \%$ & $83.06 \%$ & 4.14 & $0.00 * *$ & $69.98 \%$ & $61.65 \%$ & 3.67 & $0.00 * *$ \\
\hline SALES & $1.83 \%$ & $2.49 \%$ & 1.11 & 0.26 & $0.36 \%$ & $1.50 \%$ & 2.30 & $0.02 * *$ \\
\hline A_STURC & $1.13 \%$ & $5.09 \%$ & 5.07 & $0.00 * *$ & $9.73 \%$ & $14.29 \%$ & 4.80 & $0.00 * *$ \\
\hline \multicolumn{9}{|l|}{ Exp. for $A T$} \\
\hline AUR & $2.92 \%$ & $5.30 \%$ & 2.14 & $0.03 * *$ & $14.32 \%$ & $19.28 \%$ & 3.28 & $0.00 * *$ \\
\hline DER & $4.28 \%$ & $0.39 \%$ & 3.29 & $0.00 * *$ & $1.95 \%$ & $0.00 \%$ & 3.99 & $0.00 * *$ \\
\hline
\end{tabular}

Notes. $* *$ Significance codes $0.01 ; *$ Significance codes 0.05 .

CUR_LIQ is the main variable in explaining both the TDL and STL. Indeed, the percentage contribution is about $83 \%$, in explaining the TDL, both before and during the crisis whereas, in explaining STL, it is $70 \%$ before the crisis and $62 \%$ during the crisis. Maybe, this decrease is partially due to the increase of the percentage contribution of other variables (A_STURC and AUR), thus, it is a decrease in relative terms (only in percentage and not in absolute value). A_STURC and AUR offer very high contributions in explaining both TDL and STL, especially during the crisis. DER gives a significant contribution before the crisis, but, during the crisis, it decreases. Finally, EMPL, AGE, and SALES give weak contributions in influencing the leverage.

To judge whether these changes are significant, we made a hypothesis test to compare the differences between the regression coefficients. We compared the two TDL models and, separately, the two STL models, before and during the crisis. Table VI shows the T statistics and the P-values of the tests. These differences between the two periods are statistically significant for both TDL and STL, except for AGE and EMPL (never significant), and SALES (not significant for TDL). This analysis confirms that the effect of CUR_LIQ, A_STURC, AUR, DER, for both TDL and STL, vary significantly from the pre-crisis to the crisis period.

To better understand hypotheses H6a and H6b (regarding agency costs effects), we also refer to their percentage contribution (Table VI) for depicting which proxy exerts the strongest influence on leverage. Specifically, for TDL before the crisis, we observe that the percentage effect of AUR is $2.92 \%$ (negative influence on TDL), while the percentage contribution of DER is $4.28 \%$ (positive effect on TDL). Thus, we can state that hypothesis H6a, for TDL, is supported because the entire effect of agency costs on total leverage is positive. In contrast, for STL before the crisis, the hypothesis H6a is rejected because the total effect is negative (AUR is $14.32 \%$ and DER 1.95\%). Regarding the effect during the crisis, we highlight that, for TDL, the effect of AUR is stronger than that of DER, and thus hypothesis H6b is confirmed. Also, for STL, hypothesis H6b is confirmed because AUR and DER underline a negative effect on leverage; in effect, AUR percentage contribution is $19.28 \%$ whereas DER percentage contribution is almost null (see Table VI).

\subsection{Robustness Testing}

Because TDL is strongly distorted by the long-term component, we provide the robustness test concentrating only on STL. We computed the Shapiro-Wilk normality test for the two periods: for the model 3, the index is equal to 0.989 (p-value $=1.217 \mathrm{e}-09)$ whereas, for the model 4 , we get a value equal to 0.993 (p-value = $2.575 \mathrm{e}-06$ ). Both are very close to one, with p-values close to zero, thus we accept the null hypothesis that the residuals are normally distributed.

Two different tests are implemented to check for heteroskedasticity: the Park test (Park, 1966) and a simplified version of the White test (White, 1980). For the first, each variable present p-values greater than 0.45 , thus we can accept the null hypothesis of homoskedasticity. The second test involves the inclusion of all possible interactions between the variables taken in pairs; for both the models we obtain p-values greater than 0.3 . Thus, we can state that heteroskedasticity is not an issue of models 3 and 4 .

Furthermore, to partially mitigate the possible drawbacks of endogeneity, the independent variables are considered in previous periods with respect to the dependent variables. 


\section{Discussion and Conclusion}

In this paper, we examine whether and how the determinants of capital structure have a different impact on family firms' leverage before and during the crisis. The main element that distinguishes our study from previous researches on family firms' capital structure is that we extend the analysis to the crisis context. Indeed, previous studies focused on non-crisis contexts, then differently from the non-family firms field, we still little now about the financial behavior of family firms during the crisis. Second, this research contributes to have a more fine-grained understanding on the debt-equity choice of family firms. Moreover, our study focused only on unlisted medium sized family firms allowing us to have a more accurate picture on capital structure decisions of these firms. The literature suggests that unlisted and medium firms may be very different from listed companies in terms of their access to capital market (Crespì \& Martin-Oliver, 2015) and from small firms regarding their preferences, risk aversions, bankruptcy, and abilities to access the debt (Chittenden et al., 1996; Cressy \& Olofsson, 1997; Köksal \& Orman, 2015). Instead, previous studies have considered only small-sized family firms (e.g. López-Gracia et al., 2007) or only medium family firms but in non-crisis contexts (e.g. Gottardo \& Moisello, 2014), or family firms without differences in size or between listed and unlisted firms.

Table VII summarizes which hypotheses are accepted or not. Our results, in a perspective of comparison between the POT and TOT, reveal that the POT provides a more correct prediction than the TOT in explaining the capital structure of Italian medium-sized family firms. In particular, this is confirmed for the signs of determinants such as tangible assets, current liquidity, and size (expressed as number of employee). In particular, our results suggest that the short-term debt is negatively influenced by tangible assets (both before and during the crisis), highlighting that family firms use the short-term debt to finance non-fixed assets and use collateral to attract long-term debt. Moreover, this result reveals low information asymmetry and low agency costs between medium family firms and lenders during the crisis, confirming that family firms have low difficulties to obtain external debt finance during the crisis (Crespi \& Martín-Oliver, 2015). Moreover, our finding is consistent with many studies suggesting negative effects of STL and positive of LTL (Michaelas et al., 1999; Sogorb-Mira, 2005; Van der Wijst, N. \& Thurik, R., 1993). About current liquidity, our results show that this is the main variable in explaining both short-term debt and total debt. Specifically, it shows that the leverage is negatively affected by current liquidity, rejecting the TOT predictions and confirming the argumentations of the POT, which assumes that firms with high liquidity tend to borrow less (Deesomsak et al., 2004), and previous empirical studies (e.g. Danso \& Adomako, 2014; Gottardo \& Moisello, 2014). Also for firm size (measured by the number of employees), our results show a negative effect on short-term leverage and a positive effect on total debt as empirically demonstrated by several previous studies (e.g. Hall et al., 2004; Micheales, 1999; Sogorb-Mira, 2005). On the contrary, if firm size is measured by sales, its effect on the short-term leverage is positive during the crisis whereas before the crisis it is not significant. Effectively, an increase of sales may probably generate an increase of illiquidity in a context of crisis because small and medium firms generally exert a minor pressure in collecting payments from customers, and late payments are often financed by trade credit, which is the first preference for the POT (Degryse et al., 2012). These findings confirm the conclusions of previous studies on family firms' financial behaviors which have highlighted that the picking order framework appears to fit better with family firms' financial decisions (Croci et al., 2011; Gonzalez et al., 2013; Mahérault, 2004; Romano et al., 2000; Poutziouris, 2001; Wu et al., 2007).

However, the POT does not match all of the observed capital structure determinants. In particular, the POT does not generate prediction for one of the main determinant of its theoretical argumentations that is profitability. Instead, it is not significant neither before the crisis nor during. This is an unexpected result, as profitability is one of the main variables used by existing research to explain the preference of family firms for internal resources and for their behavior closer to the POT. This result may suggest that, even if family firms have a strong preference for internal funds in their investment decisions, when they decide to use debt, lenders evaluate other factors such as size, age, their reputation or their long-term orientation, and their intention to maintain control across generations. For example, Crespi \& Martín-Oliver (2015) have shown that during the crisis, lenders are less reluctant to lend money to family firms due to their long-term perspective and their control across generations.

Our research also highlights the relevance of agency costs in explaining family firms' capital structure. The presence of opportunistic behaviors of management, during the crisis period, is emphasized by the AUR decrease. In effect, this reduction does not seem to be caused by SALES (that is a component of AUR ratio), because the latter decreases $2.8 \%$, while AUR decreases $12.69 \%$. Our findings also underline that AUR has a positive effect on STL, and this is consistent with the risk-efficiency hypothesis (Margaritis et al., 2010); indeed, it states that efficient firms have lower risks of bankruptcy and financial distresses, and thus they choose a higher leverage 
ratio. This implies that during the crisis, when a family firm has low efficiency (high agency costs), it does not choose the debt to discipline management opportunistic behaviors. This result seems to suggest that the main important objective that drives family firms' capital structure choices is to safeguard the control on the business and the operational autonomy. This finding also contributes to better understand the contingency that can influence the dynamic of agency conflicts in family firms highlighting how the context of crisis change the dynamic of agency conflicts.

Table VII. Hypotheses regarding the impact of firm factors on total leverage ratio in pre-crisis and crisis period

\begin{tabular}{|c|c|c|c|c|}
\hline Firm's Factor & $\begin{array}{l}\text { Hypotheses for } \\
\text { pre-crisis period }\end{array}$ & $\begin{array}{l}\text { Results in pre-crisis } \\
\text { period }\end{array}$ & $\begin{array}{l}\text { Hypotheses for } \\
\text { crisis period }\end{array}$ & $\begin{array}{l}\text { Results in crisis } \\
\text { period }\end{array}$ \\
\hline Age & (H1a) - & - & (H1b) - & - \\
\hline Size & $(\mathrm{H} 2 \mathrm{a})$ & - & (H2b) & - \\
\hline Profitability & (H3a) & Not significant & (H3b) & Not significant \\
\hline Asset Structure & (H4a) & - & (H4b) & - \\
\hline Current Liquidity & (H5a) & - & (H5b) & - \\
\hline Agency Costs & $(\mathrm{H} 6 \mathrm{a})+$ & + & (H6b) & - \\
\hline
\end{tabular}

Our overall results emphasize that no theory alone is able to fully explain the leverage of medium family firms, but a more exhaustive understanding of their capital structure may be achieved through the combined use of different theories. Moreover, about the debt choice, our study reveals that family firms follow an order of preference between short-term and long-term debts as assumed by the POT; however, during the crisis, their short-term debt decreases whereas the long-term debt tends to increase.

Our results have implications for managers and practitioner. Indeed, this research suggests adapting the general theory on capital structure to the specific characteristics of medium family firms. In particular, making advice to family firms, they should consider that medium family firms' financial behaviour is more suitable with the predictions of the POT, but profitability is not the key factor driving decisions between equity and debt. Hence, current liquidity and asset structure appear to be the most important variables explaining capital structure of medium family firms, both in crisis and pre-crisis period. These aspects assume particular importance with reference to the Italian context during the crisis in 2008-2009. In fact, during the crisis, there has been an increase of demand for credit to finance companies' working capital with a consequent contraction of the credit supply by banks and an increase in the cost of capital (Banca d'Italia, 2012). Managers should therefore carefully consider that, in crisis situations, the use of short-term debt may lead companies to tensions of liquidity and excessive financial charges. This condition can expose companies to an excessive risk, especially if it is combined with a decline in turnover as may occur during a crisis. Hence, during a crisis, managers should identify all possible alternatives for financing and accessing to credit, even if different from bank credit.

Moreover, considering the relevance of small and medium firms in the Italian economic context, our study also has implications for policy makers. In effect, our results show three important aspects that can be useful for financial policies for supporting medium family firms: a) medium family firm's financial behavior does not significantly change between from pre-crisis to crisis period; b) the logic that appears to guide family firm's financial decisions is to maintain the family control over the business and reduce risk; and c) medium family firms have a strong preference for short-debt that is supported by their current liquidity.

Nevertheless, our paper is not without limits requiring further investigations. First, our results are not generalizable because our investigation only considers Italian medium family firms. Future studies should consider international comparison in order to analyze whether country-related aspects may affect these findings (Antoniou et al., 2008) also during the crisis. Second, we have compared the pre-crisis and crisis period, but a more complete understanding of the financial behavior of a firm may be achieve comparing the capital structure before, during, and after the crisis. Second, we remark that the determinants of the long-term debt still remain unclear for Italian medium family firm. Probably, these are related to the specific nature and essence of family firms, and then its determinants may be linked to behavioral aspect that future research should investigate.

\section{References}

Aiyar, S. (2015). From financial crisis to Great Recession: The role of globalized banks. American Economic Review, 102(3), 225-230. https://doi.org/10.1257/aer.102.3.225

Ampenberger, M., Scmid, T., Achleitner, A. K., \& Kaserer, C. (2013). Capital structure decisions in family firms: empirical evidence from a bank-based economy. Review of Managerial Science, 7(3), 247-275. https://doi.org/10.1007/s11846-011-0077-2

Anderson, R. C., \& Reeb, D. M. (2003). Founding family ownership and firm performance: evidence from the 
S\&P 500. Journal of Finance, 58(3), 1301-1329. https://doi.org/10.1111/1540-6261.00567

Anderson, R. C., Mansi, A. M., \& Reeb, D. M. (2003). Founding family ownership and the agency cost of debt. Journal of Financial Economics, 68(2), 263-285. https://doi.org/10.1016/S0304-405X(03)00067-9

Ang, J. S., Cole, A. R., \& Lin, J. W. (2000). Agency costs and ownership structure. Journal of Finance, 55(1), 81-106. https://doi.org/10.1111/0022-1082.00201

Antoniou, A., Guney, Y., \& Paudyal, K. (2008). The determinants of capital structure: capital market-oriented versus ban-oriented institutions. Journal of Financial \& Quantitative Analysis, 43(1), 59-92. https://doi.org/10.1017/S0022109000002751

Attig, N., Boubakri, N., El Ghoul, S., \& Guedhami, O. (2015). The Global Financial Crisis, Family Control, and Dividend Policy. Financial Management, 45(2), 291-313. https://doi.org/10.1111/fima.12115

Baker, M., \& Wurgler, J. (2002). Market Timing and Capital structure. Journal of Finance, 57, 1-32. https://doi.org/10.1111/1540-6261.00414

Balios, D., Daskalakis, N., Eriotis, N., \& Vasiliou, D. (2016). SMEs capital structure determinants during severe economic crisis: the case of Greece. Cogent Economics \& Finance, 4(1), 1-11. https://doi.org/10.1080/23322039.2016.1145535

Banca d'Italia (2010). Bollettino Economico, 52. https://www.bancaditalia.it/pubblicazioni/bollettino-economico/2010-0001/index.html. Accessed 29 January 2018.

Banca d'Italia (2012). Sondaggio congiunturale sulle imprese industriali e dei servizi, 56. https://www.bancaditalia.it/pubblicazioni/sondaggio-imprese/2012-sondaggio-imprese/suppl_56_12.pdf. Accessed 22 February 2018.

Bauweraerts, J., \& Colot, O. (2012). Pecking-Order or Static Trade-off Theory in Family Firms? Evidence from Belgium. International Business Research, 5(11), 1-11. https://doi.org/10.5539/ibr.v5n11p1

Berkovitz, P., Von Breska, E., Pieńkowski, J., \& Rubianes, A. C. (2015). The impact of the economic and financial crisis on the reform of Cohesion Policy 2008-2013. Retrived from http://ec.europa.eu/regional_policy/sources/docgener/work/2015_03_impact_crisis.pdf

Berle, A. A., \& Means, G. C. (1932). The modern corporation and private property. New York, NY: McMillan.

Blanco-Mazagatos, F., de Quevedo-Puente, E., \& Castrillo, L. A. (2007). The tradeoff between financial resources and agency costs in family business: an exploratory study. Family Business Review, 20(3), 199-213. https://doi.org/10.1111/j.1741-6248.2007.00095.x

Brailsford, T. J., Oliver, B. R., \& Pua, S. L. H. (2002). On the relation between ownership structure and capital structure. Accounting and Finance, 56(1), 87-130. https://doi.org/10.1111/1467-629X.00001

Cassar, G., \& Holmes, S. (2003). Capital structure and financing of SMEs: Australian evidence. Accounting and Finance, 43(2), 123-147. https://doi.org/10.1111/1467-629X.t01-1-00085

Centro Studi Confindustria, L'economia italiana nella crisi globale. Assetti internazionali, politiche economiche, competitività del Paese e reazione delle imprese. Scenari Economici, n. 4, dicembre 2008

Chiorri, C. (2010). Fondamenti di psicometria. Milan, Italy: McGraw-Hill.

Chittenden, F., Hall, G., \& Hutchinson, P. (1996). Small firm growth, access to capital markets and financial structure: review of issues and empirical investigation. Small Business Economics, 8(1), 59-67. https://doi.org/10.1007/BF00391976

Chrisman, J. J., Chua, J. H., \& Litz, R. A. (2004). Comparing the agency costs of family and non-family firms: conceptual issues and exploratory evidence. Entrepreneurship Theory and Practice, 29(4), 555-575. https://doi.org/10.1111/j.1540-6520.2004.00049.x

Coleman, S., \& Carsky, M. (1999). Sources of capital for small family-owned businesses: evidence from the National Survey of Small Business Finance. Family Business Review, 12(1), 73-86. https://doi.org/10.1111/j.1741-6248.1999.00073.x

Courville, T., \& Thompson, B. (2001). Use of structure coefficients in published multiple regression articles: $B$ is not enough. Educational and Psychological Measurement, 61(2), 229-248.

https://doi.org/10.1177/0013164401612006 
Crespi, R., \& Martin-Oliver., A. (2015). Do family firms have better access to external finance during crisis? Corporate Governance: An International Review, 23(3), 249-265. https://doi.org/10.1111/corg.12100

Cressy, R., \& Olofsson, C. (1997). The financial conditions form Swedish SMEs: survey and research agenda. Small Business Economics, 9(2), 179-194. https://doi.org/10.1023/A:1007975924164

Croci, E., Doukas, J. A., \& Gonec, H. (2011). Family control and financing decisions. European Financial Management, 17(5), 860-897. https://doi.org/10.1111/j.1468-036X.2011.00631.x

Danso, A., \& Adomako, S. (2014). Financing behaviour of firms and financial crisis. Managerial Finance, 40(12), 1159-1174. https://doi.org/10.1108/MF-04-2014-0098

De Angelo, H., \& Masulius, R. (1980). Optimal capital structure under corporate and personal taxation. Journal of Financial Economics, 8(1), 5-29.

Deesomsak, R., Paudyal, K., \& Pescetto, G. (2004). The determinants of capital structure: evidence from the Asia Pacific region. Journal of Multinational Financial Management, 14(4-5), 387-405. https://doi.org/10.1016/j.mulfin.2004.03.001

Degryse, H., de Goeij, P., \& Kappert, P. (2012). The impact of firm and industry characteristics on small firms' capital structure. Small Business Economics, 38(4), 431-447. https://doi.org/10.1007/s11187-010-9281-8

Demirguc-Kunt, A., Martinez Peria, M. S., \& Tressel, T. (2015). The impact of the global financial crisis on firm's capital structure. Working Paper Series WPS7522. Washington D. C.: The World Bank. https://doi.org/10.1596/1813-9450-7522

European Commission (2013). Small Business Act SBA, Italy. http://www.publicpolicy.it/wp-content/uploads/2013/11/italy_en.pdf. Accessed 29 January 2018.

European Commission (2014). Small Business Act SBA, Italy. http://ec.europa.eu/enterprise/policies/sme/small-business-act/index_en.htm. Accessed 29 January 2018.

Fama, E. F., \& Jensen, M. C. (1983). Agency problem and residual claims. Journal of Law \& Economics, 26(2), 325-344. https://doi.org/10.1086/467038

Frank, M. Z., \& Goyal, V. (2009). Capital structure decision: which factors are reliably important? Financial Management, 38(1), 1-37. https://doi.org/10.1111/j.1755-053X.2009.01026.x

Friedman, E., Johnson, S., \& Mitton, T. (2003). Propping and Tunneling. Journal of Comparative Economics, 31(4), 732-750. https://doi.org/10.1016/j.jce.2003.08.004

Gallo, M. A., \& Vilaseca, A. (1996). Finance in family business. Family Business Review, 9(4), 387-401. https://doi.org/10.1111/j.1741-6248.1996.00387.x

Gallo, M. A., Tapies, J., \& Cappunis, K. (2004). Comparison of family and non-family business: financial logic and personal preferences. Family Business Review, 17(4), 303-318. https://doi.org/10.1111/j.1741-6248.2004.00020.x

Gómez-Mejía, L. R., Haynes, K. T., Núñez-Nickel, M., Jacobson, K. J., \& Moyano-Fuentes J. (2007). Socioemotional wealth and business risks in family-controlled firms: Evidence from Spanish olive oil mills. Administrative Science Quarterly 52(1), 106-137. https://doi.org/10.2189/asqu.52.1.106

Gonzalez, M., Guzmàn, A., Pombo, C., \& Trujillo, M. A. (2013). Family firms and debt: risk aversion versus risk of losing control. Journal of Business Research, 66(11), 2308-2320. https://doi.org/10.1016/j.jbusres.2012.03.014

Gottardo, P., \& Moisiello, A. M. (2014). The capital structure choices of family firms: evidence from Italian medium-large unlisted firms. Managerial Finance, 40(3), 254-275. https://doi.org/10.1108/MF-03-2013-0065

Hall, G. C., Hutchinson, P. J., \& Michaelas, N. (2004). Determinants of the Capital Structures of European SMEs. Journal of Business Finance Accounting, 31(5-6), 711-728. https://doi.org/10.1111/j.0306-686X.2004.00554.x

Harris, M., \& Raviv, A. (1991). The theory of capital structure. Journal of Finance, 46(1), 297-355. https://doi.org/10.1111/j.1540-6261.1991.tb03753.x

ISTAT. (2011). Censimento industria e servizi. Retrived from www.istat.it

Jensen, M. (1986). Agency costs of free cash flow, corporate finance, and takeovers. American Economic Review, 
76(2), 323-330.

Jensen, M., \& Meckling, W. (1976). Theory of the firm: managerial behavior, agency costs and ownership structure. Journal of Financial Economics, 3(4), 305-360. https://doi.org/10.1016/0304-405X(76)90026-X

Koropp, C., Grichnik, D., \& Kellermans, F. W. (2013). Financial attitudes in family firms: Opening the black box. Journal of Small Business Management, 51(1), 114-137. https://doi.org/10.1111/j.1540-627X.2012.00380.x

Koropp, C., Kellermanns, F. W., Grichnik, D., \& Stanley, L. (2014). Financial decision making in family firms: an adaptation of the theory of planned behavior. Family Business Review, 27(4), 307-327. https://doi.org/10.1177/0894486514522483

Kumar, S., Colombage, S., \& Rao, P. (2017). Research on capital structure determinants: a review and future direction. International Journal of Managerial Finance, 13(2), 106-132. https://doi.org/10.1108/IJMF-09-2014-0135

Köksal, B., \& Orman, C. (2015). Determinants of capital structure: evidence from a major developing economy. Small Business Economics, 44(2), 255-282. https://doi.org/10.1007/s11187-014-9597-x

La Porta, R., Lopez-de-Silanes, F., Shleifer, A., \& Vishny, R. (1999). Corporate ownership around the world. Journal of Finance, 54(2), 471-517. https://doi.org/10.1111/0022-1082.00115

Lopez-Garcia, J., \& Sànchez-Andujar, S. (2007). Financial structure of the family business: evidence from a group of small Spanish firm. Family Business Review, 20(4), 269-287. https://doi.org/10.1111/j.1741-6248.2007.00094.x

Lubaktin, M., Shulze, W., Ling, Y., \& Dino, R. (2005). The effect of parental altruism on the governance of family-managed firms. Journal of Organizational Behavior, 26(3), 313-330. https://doi.org/10.1002/job.307

Mac An Bhaird, C., \& Lucey, B. (2010), Determinants of capital structure in Irish SMEs. Small Business Economics, 35(3), 357-375. https://doi.org/10.1007/s11187-008-9162-6

Mahérault, L. (2004). Is there any specific equity route for small and medium-sized family businesses? The French experience. Family Business Review, 17(3), 123-132. https://doi.org/10.1111/j.1741-6248.2004.00015.x

Margaritis, D., \& Psillaki, M. (2010). Capital structure, equity ownership and firm performance. Journal of Banking \& Finance, 34(3), 621-632. https://doi.org/10.1016/j.jbankfin.2009.08.023

Mateev, M., Poutziouris, P., \& Ivanov, K. (2013). On the determinants of SME capital structure in Central and Eastern Europe: a dynamic panel analysis. Research in International Business and Finance, 27(1), 28-51. https://doi.org/10.1016/j.ribaf.2012.05.002

Michaelas, N., Chitenden, F., \& Poutziouris, P. (1999). Financial policy and capital structure choice in UK SMEs: empirical evidence from company panel data. Small Business Economics, 12(2), 113-130. https://doi.org/10.1023/A:1008010724051

Miller, D., Le Berton-Miller, I., \& Scholnick, B. (2008). Stewardship vs. Stagnation: an empirical comparison of small family and non-family business. Journal of Management Studies, 45(1), 51-78.

Mishkin, F. S. (1991). Asymmetric Information and Financial Crisis: a historical perspective, In R.G. Hubbard (Ed.), Financial Market and Financial Crises, University of Chicago Press (pp. 69-108).

Mishkin, F. S. (1992). Anatomy of Financial Crisis. Journal of Evolutionary Economics, 2, 115-130. https://doi.org/10.1007/BF01193536

Modigliani, F., \& Miller, M. H. (1958). The cost of capital corporation finance and the theory of investment. The American Economic Review, 48(3), 261-297.

Modigliani, F., \& Miller, M. H. (1963). Corporate income taxes and the cost of equity: a correction. American Economic Review, 53(3), 433-443.

Muijs, W. K. (2015). The impact of the financial crisis on the determinants of capital structure. Evidence from Dutch listed firms. Retrived from http://essay.utwente.nl/67498/1/Muijs_BA_MB.pdf

Myers, S. C. (1984). The capital structure puzzle. Journal of Finance, 39(3), 575-592. https://doi.org/10.2307/2327916

Myers, S. C. (2001). Capital Structure. The Journal of Economic Perspective, 15(2), 81-102. https://doi.org/10.1257/jep.15.2.81 
Myers, S. C., \& Majluf, N. S. (1984). Corporate financing and investment decision when firms have information that investor do not have. Journal of Financial Economics, 13(2), 187-221. https://doi.org/10.1016/0304-405X(84)90023-0

Ozkan, A. (2001). Determinants of capital structure and adjustment to long run target: evidence from UK company panel data. Journal of Business Finance \& Accounting, 28(1-2), 175-198. https://doi.org/10.1111/1468-5957.00370

Park, R. E. (1966). Estimation with Heteroscedastic Error Terms. Econometrica, 34(4), 888. https://doi.org/10.2307/1910108

Poutziouris, P. (2001). The views of family companies on venture capital: empirical evidence from the UK small to medium-size enterprising economy. Family Business Review, 14(3), 277-291. https://doi.org/10.1111/j.1741-6248.2001.00277.x

Proença, P., Laureano, R. M. S., \& Laureano, L. M. S. (2014). Determinants of capital structure and the 2008 financial crisis: evidence from Purtuguese SMEs. Procedia- Social and Behavioral Science, 150, 182-191. https://doi.org/10.1016/j.sbspro.2014.09.027

Rajan R. G., \& Zingales, L. (1995). What do we know about capital structure? Some evidences from international data. Journal of Finance, 50(5), 1421-1460. https://doi.org/10.1111/j.1540-6261.1995.tb05184.x

Romano, C. A., Tanewski, G. A., \& Smyrnios, K. X. (2000). Capital structure decision making: a model for family business. Journal of Business Venturing, 16(3), 285-310. https://doi.org/10.1016/S0883-9026(99)00053-1

Santos, M. S., Moreira, A. C., \& Vieira, E. S. (2014). Ownership concentration, contestability, family firms, and capital structure. Journal of Management \& Governance, 18(4), 1063-1107. https://doi.org/10.1007/s10997-013-9272-7

Schulze, W. S., Lubatkin, M. H., \& Dino, R. N. (2003b). Toward a theory of agency and altruism in family firms. Journal of Business Venturing, 18(4), 473-490. https://doi.org/10.1016/S0883-9026(03)00054-5

Schulze, W. S., Lubatkin, M. H., Dino, R. N., \& Bucholtz, A. K. (2001). Agency relationship in family firms: theory and evidence. Organization Science, 12(2), 99-116. https://doi.org/10.1287/orsc.12.2.99.10114

Schulze, W. S., Lubatkin., M. H., \& Dino, R. N. (2003a). Exploring the agency consequences of ownership dispersion among the directors of private family firms. The Academy of Management Journal, 46(2), 79-194. https://doi.org/10.2307/30040613

Singh, M., \& Davidson, W. (2003). Agency costs, ownership structure and corporate governance mechanisms. Journal of Banking and Finance, 27(5), 93-816. https://doi.org/10.1016/S0378-4266(01)00260-6

Sogorb-Mira, F. (2005). How SME uniqueness affects capital structure: evidence from a 1994-1998 Spanish data panel. Small Business Economic, 25(5), 447-457. https://doi.org/10.1007/s11187-004-6486-8

Sparks, R. S., Zucchini, W., \& Coutsourides, D. (1985). On Variable Selection in Multivariate Regression. Communications in Statistics-Theory and Methods, 14(7), 1569-1587. https://doi.org/10.1080/03610928508828996

Steijvers, T., \& Voordeckers, W. (2009). Private family ownership and the agency costs of debt. Family Business Review, 22(4), 333-346. https://doi.org/10.1177/0894486509338291

Stulz, R. (1988). Managerial control of voting rights: financing policies and the market for corporate control. Journal of Financial Economics, 20(1-2), 25-54. https://doi.org/10.1016/0304-405X(88)90039-6

Titman, S., \& Wesseles, R. (1988). The determinants of capital structure choice. Journal of Finance, 43(1), 1-19. https://doi.org/10.1111/j.1540-6261.1988.tb02585.x

Tse, C. B., \& Rodgers, T. (2014). The capital structure of Chinese listed firms: is manufacturing industry special?. Managerial Finance, 40(5), 469-486. https://doi.org/10.1108/MF-08-2013-0211

Van der Wijst, N., \& Thurik, R. (1993). Determinants of small firm debt ratios-an analysis of retail panel data. Small Business Economics, 5(1), 55-65. https://doi.org/10.1007/BF01539318

Van Hoang, T. H., Gurău, C., \& Lahiani, A. (2018). Do crisis impact capital structure? A study of French micro-enterprises. Small Business Economics, 50, 181-199. https://doi.org/10.1007/s11187-017-9899-x

Venanzi, D., \& Naccarato, A. (2017). The Capital Structure Choice of European Firms: The Role of Financial 
System and Institutional Setting. International Business Research, 10(12), 22-47. https://doi.org/10.5539/ibr.v10n12p22

Villalonga, B., \& Amit, R. (2006). How do the family ownership, control and management affect firm value? Journal of Financial Economics, 80(2), 385-417. https://doi.org/10.1016/j.jfineco.2004.12.005

White, H. (1980). A Heteroscedasticity Consistent Covariance Matrix Estimator and a Direct Test of Heteroscedasticity. Econometrica, 48(4), 817-818. https://doi.org/10.2307/1912934

Wu, Z., Chua, J. H., \& Chrisman, J. J. (2007). Effects of family ownership and management on small business equity financing. Journal of Business Venturing, 22(6), 726-751. https://doi.org/10.1016/j.jbusvent.2006.07.002

Zahra, S. A. (2005). Entrepreneurial risk taking in family firms. Family Business Review, 18(1), 23-40. https://doi.org/10.1111/j.1741-6248.2005.00028.x

\section{Copyrights}

Copyright for this article is retained by the author(s), with first publication rights granted to the journal.

This is an open-access article distributed under the terms and conditions of the Creative Commons Attribution license (http://creativecommons.org/licenses/by/4.0/). 